\title{
澜沧江西双版纳段鱼类组成和物种多样性
}

\author{
付贵权 ${ }^{1,2,3,4}$,秦 涛 $^{1,2,3}$, 陈小勇 ${ }^{1,2, *}$, 雷春云 ${ }^{4}$, 李光华 ${ }^{4}$ \\ 1 中国科学院昆明动物研究所,昆明 650201 \\ 2 中国科学院东南亚生物多样性研究中心, 缅甸 内比都 05282 \\ 3 中国科学院大学, 北京 100049 \\ 4 云南省渔业科学研究院,昆明 650111
}

摘要:根据 2018一-2020 年澜沧江西双版纳段 5 次鱼类资源调查数据,结合相关文献资料,对该流域鱼类组成及物种多样性进行 了分析。结果显示: 澜沧江西双版纳段此次共调查到鱼类 119 种,隶属于 11 目 28 科 79 属, 而历史记录鱼类共 179 种,隶属于 12 目 34 科 106 属。随着调查的不断深人, 土著鱼类种数逐渐增多,但占比却逐渐下降,外来鱼类种数逐渐增多, 占比也逐渐升 高; 本次调查到土著鱼类 92 种, 占鱼类种数的 $77.31 \%$, 占比进一步下降; 外来鱼类 27 种, 占鱼类种数的 $22.69 \%$, 占比进一步升 高。该区域鱼类优势种为云南吻孔鲃 Poropuntius huangchuchieni 和少鳞舟齿鱼 Scaphiodonichthys acanthopterus, 常见种为长臀鲃 Mystacoleucus marginatus 和宽额鳢Channa gachua。有《国家重点保护野生动物名录》(2021 年) 鱼类 5 种, 《中国生物多样性红 色名录 脊椎动物卷》(2015 年) 受威胁鱼类 8 种。相对于我国其他江河, 澜沧江西双版纳段有极高水平的鱼类物种多样性, 其 中阑沧江干流鱼类物种多样性相对于左、右岸支流较低,左岸支流鱼类多样性高于右岸,罗梭江鱼类多样性高于其他一级支流。 虽然澜沧江西双版纳段鱼类物种多样性维持在较高水平,但土著鱼类占比下降趋势明显,仍面临着严重威胁, 本文分析了受威 胁因素,并提出了保护建议。

关键词: 鱼类组成; 物种多样性; 澜沧江; 西双版纳

\section{Composition and species diversity of fishes in Xishuangbanna reach of Lancang River}

FU Guiquan ${ }^{1,2,3,4}$, QIN Tao ${ }^{1,2,3}$, CHEN Xiaoyong ${ }^{1,2, *}$, LEI Chunyun ${ }^{4}$, LI Guanghua ${ }^{4}$

1 Kunming Institute of Zoology, Chinese Academy of Sciences, Kunming 650201, China

2 Southeast Asia Biodiversity Research Institute, Chinese Academy of Sciences, Nay Pyi Taw 05282, Myanmar

3 University of Chinese Academy of Sciences, Beijing 100049, China

4 Yunnan Institute of Fishery Sciences Research, Kunming 650111, China

\begin{abstract}
Based on the data from five surveys of fish resources during 2018-2020 and literature, the fish composition and species diversity in Xishuangbanna reach of Lancang River are analyzed. The results show that there are 11 orders, 28 families , 79 genera and 119 species of fish being collected, while a total of 179 valid fish species are recorded, belonging to 12 orders, 34 families and 106 genera. With the deepening of the investigation, the number of indigenous fish species is increasing, but the proportion is decreasing; while the number of exotic fish species is increasing, and the proportion is increasing. In these surveys, 92 species of indigenous fish are found, accounting for $77.31 \%$ of the total number of fish species, and the proportion decreases further. 27 species of exotic fish are collected, accounting for 22.69\%, the proportion

基金项目:生态环境部生物多样性调查;观测和评估项目(2019-2023 年);科技部澜沧江-湄公河合作专项基金(澜沧江-湄公河流域生物多样性 监测与网络建设项目); 中国科学院东南亚生物多样性研究中心项目(Y4ZK111B01)

收稿日期: 2021-04-14; 采用日期: 2021-09-01

*通讯作者 Corresponding author.E-mail: chenxy@ mail.kiz.ac.cn
\end{abstract}


increases accordingly. The dominant species of fish are Poropuntius huangchuchieni and Scaphiodonichthys acanthopterus, and common species are Mystacoleucus marginatus and Channa gachua. Five fish species are listed on the List of Key Protected Wild Animals in China (2021) and eight species as threatened species in the Redlist of China's Biodiversity: Vertebrate (2015). Fish species diversity in Xishuangbanna reach of Lancang River is extremely high among river of China. The fish species diversity of the main stem of Lancang River is lower than that of tributaries, while that of the left bank tributary is higher than the right bank, and that of the Luosuo River is higher than that of other tributaries. Although the fish species diversity maintains a high level in Xishuangbanna reach of Lancang River, the proportion of indigenous fish is declining obviously and it is still facing serious threats. The threats are analyzed and some suggestions on conservation are proposed.

Key Words : fish composition; species diversity; Lancang River; Xishuangbanna

澜沧江发源于唐古拉山北麓海拔 $5514 \mathrm{~m}$ 的果宗木查山 ${ }^{[1]}$, 流经青海、西藏、云南三省区后,于云南省预腊 县出境,始称湄公河, 自北向南又流经缅甸、老挝、泰国、柬埔寨,最后在越南注人南中国海 ${ }^{[2-3]}$ 。澜沧江-湄公 河鱼类物种多样性极高, 其中老挝南端至源头的中上游流域共记录淡水鱼类 745 种 $^{[4]}$, 整个流域估计有鱼类 物种 1200-1300 种 ${ }^{[5-6]}$ 。西双版纳傣族自治州地处云南省南部边缘, 位于东经 $99^{\circ} 56^{\prime}-101^{\circ} 50^{\prime}$, 北纬 $21^{\circ} 08^{\prime}-22^{\circ} 36^{\prime}$ 之间, 北接横断山脉, 南连中南半岛, 处于热带向亚热带的过渡地带, 是印度一马来热带区的最 北缘,气候终年温暖湿润,植物种类繁多而茂密,为热带、亚热带动物提供了丰富的食物和各自适宜的栖息繁 衍场所, 是物种高度多样性的地区之一, 素有 “种质资源基因库” 的誉称 ${ }^{[7-9]}$ 。西双版纳属澜沧江-湄公河水 系, 境内河网密布、纵横深切、生境多样,鱼类资源丰富 ${ }^{[9-19]}$, 褚新洛和陈银瑞 ${ }^{[10]}$ 于 1987 年较为系统地调查整 理了西双版纳鱼类名录, 记录鱼类 100 种; 杨德华 ${ }^{[9]}$ 于 1993 年报道了西双版纳鱼类 92 种; 随着国内外学者对 西双版纳鱼类研究的深人, 更多新种或新纪录被发现 ${ }^{[20-29]}$, 但对西双版纳鱼类物种多样性的相关研究较少。 本文基于近三年对西双版纳鱼类资源调查研究的最新成果, 结合历史文献资料 ${ }^{[4,9-41]}$, 对澜沧江西双版纳段 鱼类组成和现状进行整理汇总, 分析鱼类组成特点、物种多样性变化和受威胁因素, 并对鱼类资源保护提出相 应对策。

\section{1 材料与方法}

\section{1 研究区域}

澜沧江一湄公河在西双版纳州境内干流长 $184 \mathrm{~km}$, 主要支流有罗梭江、南腊河、南览河、南阿河、流沙河、 南果河、预养河、南肯河等 ${ }^{[7]}$ 。按照澜沧江河流流向, 澜沧江流域西双版纳段划分为澜沧江干流、澜沧江左岸 支流和澜沧江右岸支流。根据鱼类生物学特性和栖息地特征, 在澜沧江西双版纳段共设置 40 个采样点 (表 1 和图 1)。

\section{2 调查时间}

2018 年 12 月一 2019 年 1 月对西双版纳罗梭江流域鱼类资源进行了调查, 2019 年 9 月和 2020 年 9 月对 西双版纳鱼类资源进行了系统调查,2019 年 6 月-7 月、2020 年 6 月-7 月对西双版纳罗梭江流域鱼类早期 资源进行了调查。

\section{3 调查方法}

本次调查包括历史文献查阅和野外调查相结合的方法。历史文献参阅各志书以及发表的新种、新纪录 等 ${ }^{[4,9-41]}$,排除同物异名,更新分类地位变动,整理成三个阶段(截至 1990 年,截至 2013 年,截至 2020 年) 的 历史记录, 有疑问的种类未收录, 如: 东方墨头鱼 Garra orientalis、南方鳅鮀 Gobiobotia meridionalis、间鱼骨 Hemibarbus medius、后背鲇鲤 Percocypris retrodorslis、飘鱼Pseudolaubuca sinensis、裸腹叶须鱼 Ptychobarbus kaznakovi、刺鯺鳑鲏 Rhodeus spinalis、横纹南鳅 Schistura fasciolata、密纹南鲀 Schistura vinciguerrae、版纳金线鲃 
Sinocyclocheilus bannaensis、宽鳍鱲Zacco platypus 等。

表 1 澜沧江西双版纳段采样点设置

Table 1 Sampling sites in Xishuangbanna reach of Lancang River

\begin{tabular}{|c|c|c|c|c|c|}
\hline $\begin{array}{l}\text { 编号 } \\
\text { Number }\end{array}$ & $\begin{array}{l}\text { 调查样点 } \\
\text { Sampling sites }\end{array}$ & $\begin{array}{l}\text { 河流 } \\
\text { Rivers }\end{array}$ & $\begin{array}{l}\text { 纬度 }\left(^{\circ}\right) \\
\text { Latitude }\end{array}$ & $\begin{array}{l}\text { 经度 }\left({ }^{\circ}\right) \\
\text { Longitude }\end{array}$ & $\begin{array}{l}\text { 海拔/m } \\
\text { Altitude }\end{array}$ \\
\hline 1 & 景栋厂 & 澜沧江干流 & 22.031082 & 100.788457 & 537 \\
\hline 2 & 流沙河汇口 & 澜沧江与流沙河汇口 & 21.990843 & 100.830951 & 550 \\
\hline 3 & 预罕镇 & 澜沧江干流 & 21.851637 & 100.922697 & 519 \\
\hline 4 & 罗梭江汇口 & 澜沧江与罗梭江汇口 & 21.815992 & 101.15972 & 513 \\
\hline 5 & 关累口岸 & 澜沧江干流 & 21.689159 & 101.12879 & 491 \\
\hline 6 & 南腊河汇口 & 澜沧江与南腊河汇口 & 21.568754 & 101.140864 & 479 \\
\hline 7 & 大河边村 & 预养河 & 22.205925 & 100.759682 & 627 \\
\hline 8 & 曼乐村 & 南肯河 & 22.361948 & 100.85557 & 927 \\
\hline 9 & 跳坝河村 & 罗梭江支流南线河 & 22.178142 & 101.007452 & 736 \\
\hline 10 & 大窝塘 & 罗梭江支流普文河 & 22.392356 & 101.115846 & 834 \\
\hline 11 & 大开河村 & 罗梭江支流普文河 & 22.580705 & 101.017771 & 1010 \\
\hline 12 & 老黄寨村 & 罗梭江支流尔旺河 & 22.46484 & 101.210818 & 1085 \\
\hline 13 & 踏青河汇口 & 罗梭江与踏青河汇口 & 22.585078 & 101.445365 & 832 \\
\hline 14 & 曼帕村 & 罗梭江 & 22.212998 & 101.201552 & 678 \\
\hline 15 & 曼配村 & 罗梭江 & 21.994215 & 101.277963 & 568 \\
\hline 16 & 曼打鸠村 & 罗梭江 & 21.926132 & 101.272745 & 535 \\
\hline 17 & 曼赛村 & 罗梭江支流曼赛河 & 22.10466 & 101.256568 & 653 \\
\hline 18 & 曼着村 & 罗梭江支流磨着河 & 21.97556 & 101.350963 & 584 \\
\hline 19 & 曼梭醒村 & 罗梭江支流南品河 & 21.87873 & 101.27118 & 525 \\
\hline 20 & 补蚌村 & 南腊河 & 21.599498 & 101.586992 & 672 \\
\hline 21 & 曼迈村 & 南腊河与南木窝河汇口 & 21.412878 & 101.548192 & 611 \\
\hline 22 & 曼批村 & 南腊河 & 21.436862 & 101.298667 & 564 \\
\hline 23 & 曼岗村 & 南腊河 & 21.591131 & 101.222777 & 524 \\
\hline 24 & 尚冈村 & 南腊河支流南木窝河 & 21.268088 & 101.685456 & 736 \\
\hline 25 & 曼庄村 & 南腊河支流南木窝河 & 21.416478 & 101.661425 & 666 \\
\hline 26 & 曼景东 & 流沙河 & 22.00937 & 100.728293 & 552 \\
\hline 27 & 曼拉村 & 流沙河 & 21.954825 & 100.338167 & 1175 \\
\hline 28 & 曼行村 & 流沙河 & 21.895003 & 100.223398 & 1232 \\
\hline 29 & 预混镇 & 流沙河 & 21.859208 & 100.386834 & 1192 \\
\hline 30 & 䉝笆桥 & 南果河 & 22.241417 & 100.376235 & 1039 \\
\hline 31 & 纳丙村 & 南果河 & 22.265309 & 100.268909 & 1279 \\
\hline 32 & 南达村 & 南览河 & 22.129233 & 100.044098 & 812 \\
\hline 33 & 打洛村 & 南览河 & 21.698042 & 100.052067 & 634 \\
\hline 34 & 预板村 & 南览河支流南擞河 & 21.737075 & 100.202882 & 683 \\
\hline 35 & 新龙村 & 南览河支流南桔河 & 21.611613 & 100.258252 & 758 \\
\hline 36 & 预因村 & 南阿河 & 21.616663 & 100.505067 & 1002 \\
\hline 37 & 曼南坎村 & 南阿河 & 21.590988 & 100.650497 & 647 \\
\hline 38 & 嘎因村 & 南阿河 & 21.697208 & 100.722397 & 616 \\
\hline 39 & 曼岛 & 南阿河 & 21.696393 & 100.815625 & 597 \\
\hline 40 & 土鲁村 & 南阿河 & 21.692799 & 100.876746 & 571 \\
\hline
\end{tabular}

野外调查按照环境保护部公告 2017 年第 84 号《县域生物多样性调查与评估相关技术规定》之《内陆鱼 类多样性调查与评估技术规定》和环境保护部《生物多样性观测技术导则 内陆水体鱼类》(HJ 710.7-2014), 


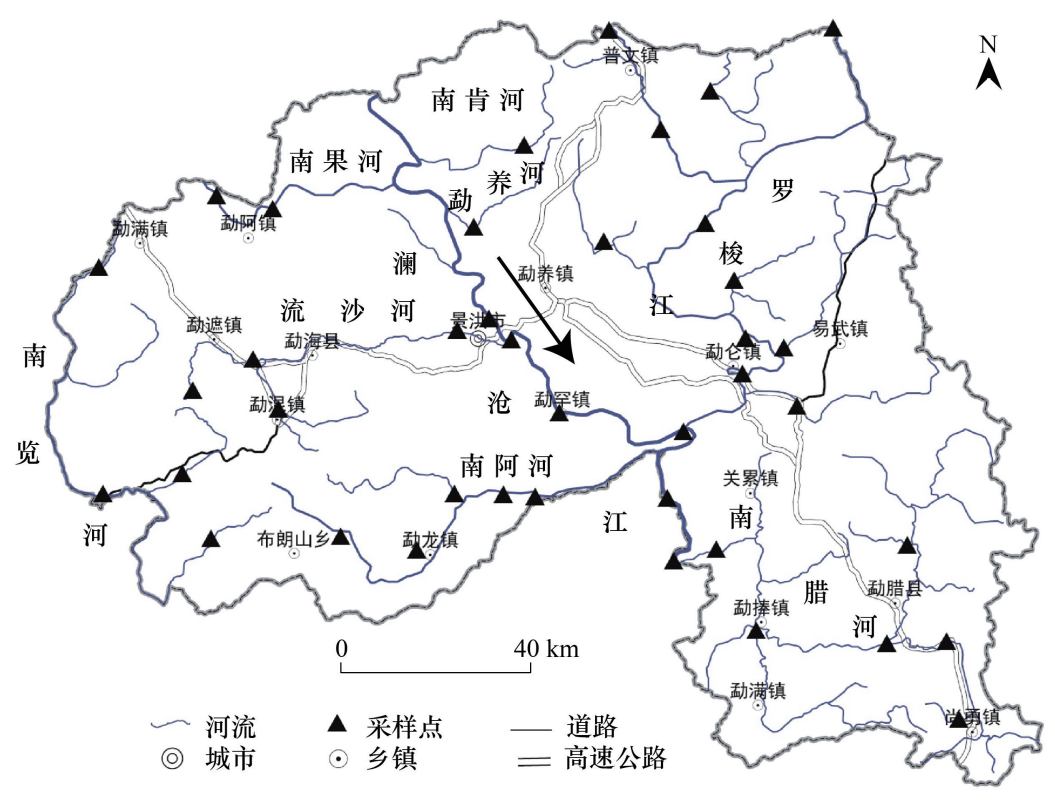

图 1 澜沧江西双版纳段采样点分布图

Fig.1 Map showing sampling sites in Xishuangbanna reach of Lancang River

并参照《水库渔业资源调查规范》(SL 167-96)、《内陆水域渔业自然资源调查手册》 ${ }^{[42]}$ 等进行, 主要包括现场 调查、渔获物调查、鱼类早期资源调查、访问调查等。现场调查主要采用撒网、流刺网、地笼等方法获取鱼类标 本; 渔获物调查主要通过采买渔民或市场的野生鱼类获取标本; 早期资源调查主要用弶网进行采集,通过 DNA 条形码进行物种鉴定; 访问调查主要是访问渔民、渔业管理人员等, 以影音、活体或标本资料为依据, 如 无影音、活体、标本资料或产地来源不明的不计人本次调查数据之列, 如哈氏方口鲃 Cosmochilus harmandi、弓 背鱼 Notopterus notopterus、光唇裂腹鱼 Schizothorax lissolabiatus 等。依据鱼类分类学研究成果 ${ }^{[9,30-37]}$ 进行分类 鉴定。本文目科级分类系统参照陈小勇 ${ }^{[38]}$ 《云南鱼类名录》, 个别属种名称根据最新研究成果更新。中文名 参照《拉汉世界鱼类系统名典》 ${ }^{[43]}$ 。

\section{4 鱼类濒危状况}

根据《国家重点保护野生动物名录》 ${ }^{[44]}$ 和《中国生物多样性红名录 脊椎动物卷》 ${ }^{[45]}$ 评估澜沧江西双版纳 段保护鱼类和受威胁鱼类状况。

\section{5 数据分析}

(1) 采用 Pinkas 相对重要性(优势度) 指数( IRI) 分析流域内鱼类优势种及常见种 ${ }^{[46]}$, 其中 IRI 值大于等 于 1000 时为优势种, 500-1000 为常见种, 100-500 为一般种, 10-100 为少见种, 10 以下为稀有种。

$$
\text { IRI }=(N \%+W \%) \times F \% \times 10^{4}
$$

式中, $N \%$ 为某物种数量百分比; $W \%$ 为某物种质量百分比; $F \%$ 为某物种出现的采样点占总样点数的比例。

(2) 采用 $G-F$ 指数 ${ }^{[47-48]}$ 分析澜沧江西双版纳段的鱼类物种组成及多样性差异, 采用 Shannon-Wiener 多样 性指数 $\left(H^{\prime}\right)^{[49]}$ 、Pielou 均匀度指数 $\left(J^{\prime}\right)^{[50]}$, Margalef 丰富度指数 $(D)^{[51]}$ 分析澜沧江西双版纳段鱼类群落多 样性。

$F$ 指数 $\left(D_{F}\right)$ : 指科间的多样性。

$$
D_{F}=\sum_{k=1}^{m} D_{F k}=-\sum_{k=1}^{m} \sum_{i=1}^{n} P_{i} \ln P_{i}
$$

式中, $P_{i}=S_{k i} / S_{k}, S_{k i}$ 为 $k$ 科 $i$ 属中的物种数, $S_{k}$ 为 $k$ 科中的物种数, $n$ 为 $k$ 科中的属数, $m$ 为科数。

$G$ 指数 $\left(D_{G}\right)$ : 指属间的多样性。 


$$
D_{G}=\sum_{j=1}^{p} D_{G j}=-\sum_{j=1}^{p} q_{j} \ln q_{j}
$$

式中, $q_{j}=S_{j} / S, S_{j}$ 为鱼类 $j$ 属中的物种数, $S$ 为鱼类的物种数, $p$ 为鱼类的属数。

$G-F$ 指数 $\left(D_{G-F}\right)$ : 鱼类物种多样性。

$$
D_{G-F}=1-D_{G} / D_{F}
$$

式中, $G-F$ 指数是 $0-1$ 的测度, 非单种科越多, $G-F$ 指数越高; 反之, 数值就越低。

Shannon-Wiener 多样性指数 $\left(H^{\prime}\right)$

$$
H^{\prime}=-\sum_{i=1}^{S} P_{i} \ln P_{i}
$$

式中, $P_{i}$ 为第 $i$ 种个体的占总个体数的比率, $S$ 为种类数。

Pielou 均匀度指数 $\left(J^{\prime}\right)$

$$
J^{\prime}=H^{\prime} / \ln S
$$

Margalef 丰富度指数 $(D)$

$$
D=(S-1) / \ln N
$$

式中, $S$ 为种类数, $\mathrm{N}$ 为总渔获尾数。

\section{2 结果}

\section{1 鱼类种类组成现状}

本次调查共采集鱼类标本 6125 号,调查到鱼类 119 种,隶属于 11 目 28 科 79 属,鱼类早期资源调查鱼类 12 种,隶属于 2 目 4 科 10 属 (详见附录); 其中中国鱼类新纪录 5 种,云南鱼类新纪录 1 种,待定种 5 种,西双 版纳外来鱼类新纪录 15 种。鲤形目鱼类种类最多,有 74 种,占鱼类种数的 $62.18 \%$; 其次是鲇形目 19 种和鲇 形目 15 种,分别占鱼类种数的 $15.97 \%$ 和 $12.61 \%$; 其余 8 目共 11 种,占鱼类总种数的 $9.24 \%$ 。从科级水平看, 鲤科鱼类种类最多,有 48 种, 占鱼类种数的 $40.34 \%$; 其次是条鲀科 16 种和鮡科 8 种, 分别占鱼类种数 $13.45 \%$ 和 $6.72 \%$; 爬鳅科和丽鱼科各 5 种,分别占鱼类种数的 $4.20 \%$; 其余 23 科共 37 种,占鱼类种数的 $31.09 \%$ 。

\section{2 土著种和外来种的历史组成变化}

根据文献资料 ${ }^{[4,9-41]}$ 和本次调查结果统计, 截至 2020 年, 西双版纳共记录鱼类 179 种,隶属于 12 目 34 科 106 属 (详见附录), 是 1990 年(106 种)和 2013 年(145 种)的 $168.87 \%$ 和 $123.45 \%$ 。随着调查的不断深人,澜 沧江西双版纳段土著鱼类种数逐渐增多,但占比却逐渐下降; 外来鱼类种数逐渐增多, 占比也逐渐升高 (详见

\begin{tabular}{|c|c|c|c|c|c|c|c|c|}
\hline & \multicolumn{2}{|c|}{$\begin{array}{l}\text { 截至 } 1990 \text { 年 } \\
\text { By } 1990\end{array}$} & \multicolumn{2}{|c|}{$\begin{array}{l}\text { 截至 } 2013 \text { 年 } \\
\text { By } 2013\end{array}$} & \multicolumn{2}{|c|}{$\begin{array}{c}\text { 截至 } 2020 \text { 年 } \\
\text { By } 2020\end{array}$} & \multicolumn{2}{|c|}{$\begin{array}{c}\text { 本次调查 } \\
\text { The survey in 2018-2020 }\end{array}$} \\
\hline & $\begin{array}{l}\text { 种类数 } \\
\text { Species }\end{array}$ & $\begin{array}{c}\text { 占比 } \\
\text { Proportion }\end{array}$ & $\begin{array}{l}\text { 种类数 } \\
\text { Species }\end{array}$ & $\begin{array}{c}\text { 占比 } \\
\text { Proportion }\end{array}$ & $\begin{array}{l}\text { 种类数 } \\
\text { Species }\end{array}$ & $\begin{array}{c}\text { 占比 } \\
\text { Proportion }\end{array}$ & $\begin{array}{l}\text { 种类数 } \\
\text { Species }\end{array}$ & $\begin{array}{c}\text { 占比 } \\
\text { Proportion }\end{array}$ \\
\hline 土著鱼类 The indigenous fish & 100 & $94.34 \%$ & 128 & $88.28 \%$ & 147 & $82.12 \%$ & 92 & $77.31 \%$ \\
\hline 外来鱼类 The exotic fish & 6 & $5.66 \%$ & 17 & $11.72 \%$ & 32 & $17.88 \%$ & 27 & $22.69 \%$ \\
\hline 合计 Total & 106 & & 145 & & 179 & & 119 & \\
\hline
\end{tabular}
表 2)。本次调查到土著鱼类 92 种,占鱼类种数的 $77.31 \%$, 占比进一步下降;外来鱼类 27 种,占鱼类种数的 $22.69 \%$, 占比进一步升高,外来鱼类已对土著鱼类构成了严重威胁。

表 2 澜沧江西双版纳段土著鱼类和外来鱼类的历史组成变化

Table 2 The historical composition variation of indigenous and exotic fish species in Xishuangbanna reach of Lancang River

\section{3 鱼类优势种}

根据 2019 年和 2020 年澜沧江西双版纳段调查数据对该区域鱼类相对重要性( 优势度) 指数( IRI) 进行计 算得出: 澜沧江西双版纳段鱼类优势种为云南吻孔鲃 Poropuntius huangchuchieni 和少鳞舟齿鱼 Scaphiodonichthys acanthopterus, 常见种为长慰鲃 Mystacoleucus marginatus 和宽额鳢 Channa gachua,一般种为 
湄南南鳅 Schistura kengtungensis、尼罗罗非鱼Oreochromis niloticus、丽色真马口波鱼 Opsarius pulchellus、斯托利 佩西鲃Pethia stoliczkana、南方白甲鱼 Onychostoma gerlachi、华南鲤Cyprinus rubrofuscus、鲫 Carassius auratus、马 口鱼 Opsariichthys bidens 8 种,其它为少见种或稀有种。

\section{4 鱼类濒危状况}

根据 2021 年颁布的《国家重点保护野生动物名录》,西双版纳有国家重点保护鱼类 5 种,其中 I 级保护鱼 类 1 种, II 级保护鱼类 4 种。根据 2015 年颁布的《中国生物多样性红色名录 脊椎动物卷》, 西双版纳受威胁 鱼类有 8 种, 其中极危 $(\mathrm{CR})$ 鱼类 2 种, 濒危 $(\mathrm{EN})$ 鱼类有 4 种, 易危 $(\mathrm{VU})$ 鱼类 2 种; 近危 $(\mathrm{NT})$ 鱼类 13 种 (详 见表 3)。

表 3 澜沧江西双版纳段重点保护及受威胁鱼类名录

Table 3 List of key protected and threatened fish species in Xishuangbanna reach of Lancang River

\begin{tabular}{|c|c|c|}
\hline $\begin{array}{l}\text { 鱼类种类 } \\
\text { Fish species }\end{array}$ & $\begin{array}{c}\text { 国家重点保护野生动物名录 }(2021) \\
\text { The List of Key Protected } \\
\text { Wild Animals in China (2021) }\end{array}$ & $\begin{array}{c}\text { 中国生物多样性红色名录 (2015) } \\
\text { The Redlist of China's } \\
\text { Biodiversity (2015) }\end{array}$ \\
\hline 长丝鲻 Pangasius sanitwongsei & I 级 & $\mathrm{CR}$ \\
\hline 花鳗鲖 Anguilla marmorata & II 级 & EN \\
\hline 双孔鱼 Gyrinocheilus aymonieri & II 级 & \\
\hline 魾 Bagarius bagarius & II 级 & VU \\
\hline 巨魾 Bagarius yarrelli & II 级 & $\mathrm{VU}$ \\
\hline 朱氏高鲮 Altigena zhui & & $\mathrm{CR}$ \\
\hline 细纹似鳡 Luciocyprinus striolatus & & EN \\
\hline 红鯺方口鲃 Cosmochilus cardinalis & & EN \\
\hline 短须粒鲇 Akysis brachybarbatus & & EN \\
\hline 老挝魟 Dasyatis laosensis & & NT \\
\hline 双色撸鲡 Anguilla bicolor & & NT \\
\hline 大鳍鱼 Macrochirichthys macrochirius & & NT \\
\hline 云南吻孔鲃 Poropuntius huangchuchieni & & NT \\
\hline 细尾长慰鲃 Mystacoleucus lepturus & & NT \\
\hline 皮氏野鲮 Labeo pierrei & & NT \\
\hline 斑鯺连穗沙䲝 Syncrossus beauforti & & NT \\
\hline 南方连穗沙䱊 Syncrossus lucasbahi & & NT \\
\hline 叉尾鲇 Wallago attu & & NT \\
\hline 短须鲻 Pangasius micronemus & & NT \\
\hline 长慰鲱鲇 Clupisoma longianalis & & NT \\
\hline 穗缘异齿鰋 Oreoglanis setiger & & NT \\
\hline 似黄斑禇鮡 Pseudecheneis sulcatoides & & NT \\
\hline
\end{tabular}

CR: 极危 Critically Endangered;EN : 濒危 Endangered;VU: 易危 Vulnerable; NT: 近危 Near threatened

\section{5 鱼类物种多样性}

基于澜沧江西双版纳段各采样点采集到的鱼类进行统计计算 (详见表 4),澜沧江西双版纳段有较高水平 的鱼类物种多样性 $\left(H^{\prime}=3.41 ; J^{\prime}=0.78 ; D=9.36\right)$, 其中澜沧江干流鱼类物种多样性 $\left(H^{\prime}=1.85 ; J^{\prime}=0.57 ; D=4\right.$. 35 ) 相对于左、右岸支流较低, 群落结构复杂程度和丰富度不高, 鱼类物种分布的均匀程度较低; 左岸支流鱼 类科数、属数、种数、 $F$ 指数、 $G$ 指数、 $G-F$ 指数均高于右岸支流, 鱼类物种多样性 $\left(H^{\prime}=3.14 ; D=8.50\right)$ 相对右岸 $\left(H^{\prime}=3.08 ; D=6.34\right)$ 也较丰富, 但鱼类物种分布的均匀程度 $\left(J^{\prime}=0.74\right)$ 不如右岸 $\left(J^{\prime}=0.8\right)$ 。

从各一级支流鱼类物种多样性指数而言, 罗梭江 $F$ 指数、 $G$ 指数、 $G-F$ 指数均最高, 说明罗梭江鱼类群落 结构中非单种科的比例最高, 科属结构复杂程度也比其他支流较高。Shannon-Wiener 多样性指数 $\left(H^{\prime}\right)$ 结果显 示: 罗梭江>南腊河 >南览河>南阿河>流沙河 $>$ 南肯河 $>$ 预养河 $>$ 南果河, 说明罗梭江鱼类物种多样性最高, 南 
果河最低。Pielou 均匀度指数 $\left(J^{\prime}\right)$ : 南肯河 $>$ 流沙河 $>$ 南阿河 $>$ 南腊河 $>$ 南览河 $>$ 罗梭江 $>$ 㔚养河 $>$ 南果河, 说明 南果河的鱼类分布较均匀,南肯河的均匀度最低。Margalef 丰富度指数 $(D)$ : 罗梭江 $>$ 南腊河 $>$ 南览河 $>$ 南阿河 >流沙河>㔚养河>南肯河>南果河, 说明罗梭江的鱼类丰富度最高,南果河最低。

表 4 澜沧江西双版纳段各水系鱼类物种多样性比较

Table 4 Comparison of fish species diversity among streams in Xishuangbanna reach of Lancang River

\begin{tabular}{|c|c|c|c|c|c|c|c|c|c|}
\hline $\begin{array}{l}\text { 河流 } \\
\text { Rivers }\end{array}$ & $\begin{array}{l}\text { 科数 } \\
\text { Family }\end{array}$ & $\begin{array}{l}\text { 属数 } \\
\text { Genus }\end{array}$ & $\begin{array}{c}\text { 种数 } \\
\text { Species }\end{array}$ & $\begin{array}{l}F \text { 指数 } \\
F \text { index }\end{array}$ & $\begin{array}{l}G \text { 指数 } \\
G \text { index }\end{array}$ & $\begin{array}{l}G-F \text { 指数 } \\
G-F \text { index }\end{array}$ & $\begin{array}{l}\text { Shannon-Wiener } \\
\text { 多样性指数 } \\
\text { Shannon-Wiener } \\
\text { diversity index }\left(H^{\prime}\right)\end{array}$ & $\begin{array}{c}\text { Pielou } \\
\text { 均匀度指数 } \\
\text { Pielou evenness } \\
\text { index }\left(J^{\prime}\right)\end{array}$ & $\begin{array}{c}\text { Margalef } \\
\text { 丰富度指数 } \\
\text { Margalef richness } \\
\text { index }(D)\end{array}$ \\
\hline 澜沧江西双版纳段 & 28 & 79 & 119 & 10.89 & 4.14 & 0.62 & 3.41 & 0.78 & 9.36 \\
\hline 干流 & 21 & 50 & 60 & 6.12 & 3.85 & 0.37 & 1.85 & 0.57 & 4.35 \\
\hline 左岸 & 22 & 68 & 98 & 9.45 & 4.07 & 0.57 & 3.14 & 0.74 & 8.50 \\
\hline 罗梭江 & 17 & 54 & 79 & 8.15 & 3.82 & 0.53 & 2.96 & 0.73 & 7.59 \\
\hline 南腊河 & 20 & 45 & 51 & 5.16 & 3.77 & 0.27 & 2.67 & 0.76 & 5.59 \\
\hline 预养河 & 6 & 13 & 13 & 2.08 & 2.56 & -0.23 & 1.79 & 0.70 & 2.33 \\
\hline 南肯河 & 5 & 9 & 9 & 1.61 & 2.20 & -0.37 & 2.03 & 0.92 & 1.84 \\
\hline 右岸 & 15 & 39 & 50 & 6.28 & 3.50 & 0.44 & 3.08 & 0.80 & 6.34 \\
\hline 南览河 & 8 & 26 & 35 & 4.52 & 3.07 & 0.32 & 2.62 & 0.74 & 5.06 \\
\hline 南阿河 & 10 & 20 & 26 & 3.24 & 2.79 & 0.14 & 2.50 & 0.77 & 4.02 \\
\hline 流沙河 & 12 & 19 & 20 & 2.60 & 2.93 & -0.13 & 2.20 & 0.81 & 2.44 \\
\hline 南果河 & 8 & 14 & 14 & 2.71 & 2.64 & 0.03 & 1.35 & 0.58 & 1.76 \\
\hline
\end{tabular}

$F$ 指数: 指科间的多样性, $G$ 指数: 指属间的多样性, $G-F$ 指数: 指鱼类物种多样性

\section{3 分析与讨论}

西双版纳位于热带亚热带季风气候区,具有较高的气温、充沛的降雨和较高的初级生产力,鱼类物种多样 性极高 ${ }^{[7-10]}$ 。通过整理统计褚新洛等 ${ }^{[10-11,31-32]}$ 于 20 世纪 90 年代初的研究成果, 在西双版纳共记录土著鱼类 100 种; 陈小勇 ${ }^{[38]}$ 于 2013 年整理的云南鱼类名录中收录西双版纳土著鱼类 128 种; 随着调查强度的不断加大 和鱼类分类研究的不断深人,截至目前土著鱼类记录已有 147 种, 鱼类种类远高于澜沧江中上游流域 ${ }^{[52-54]}$ 。

本次调查到鱼类 119 种,其中土著鱼类 92 种,仅占土著鱼类历史记录 (147 种) 的 62.59\%。国家重点保

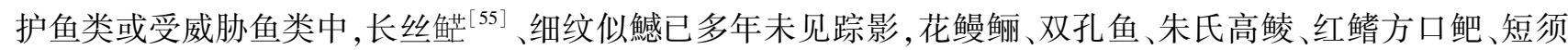
粒鲇在野外也极难见到,鮕、巨鮕野外种群数量急剧减少; 近危 (NT) 鱼类如老挝魟、双色撸鲡、大鯺鱼、短须 鲻、长臀鲱鲇及其它土著鱼类如爪哇无名鲃 Barbonymus gonionotus、盔圆唇鱼 Cyclocheilichthys armatus、鲃鲤 Puntioplites proctozysron、爪哇鲃鲤 Puntioplites waandersi、尾斑单吻鱼 Henicorhynchus caudimaculatus、长背鲃 Labiobarbus leptocheila、舌唇鱼 Lobocheilus melanotaenia、澜沧渭公鱼 Mekongina lancangensis、湄公半鲇 Hemisilurus mekongensis 等在野外也不易见到,也应列为重点保护鱼类或受威胁鱼类。

相对于我国其他江河 ${ }^{[38,56-57]}$, 澜沧江西双版纳段有极高水平的鱼类物种多样性, 主要原因是这里地处热 带向亚热带的过渡地带, 气候终年温暖湿润, 河网密布, 生境复杂多样, 河道蜿蜒曲折, 水流急缓结合, 深潭与 浅滩交错, 饵料生物充足, 人为干扰相对较少, 部分河段仍维持原始生境,这为不同生境的鱼类提供了良好丰 富多样的栖息场所、食物来源, 也为洄游鱼类提供了重要的产卵场所, 蕴育了丰富的鱼类物种多样 性 ${ }^{[14-15,55,58-59]}$ 。澜沧江干流鱼类物种多样性相对于左、右岸支流较低, 主要原因是干流生境较支流更单一, 与 王莹 ${ }^{[59]}$ 对罗梭江鱼类物种多样性略高于澜沧江干流的研究结论相一致。左岸支流鱼类物种多样性高于右 岸, 罗梭江高于其他一级支流, 主要是由罗梭江河流生境的复杂程度决定的 ${ }^{[14-15,58-59]}$; 左岸支流主要是罗梭 江、南腊河、预养河和南肯河, 右岸支流主要是南阿河、南览河、流沙河和南果河, 左岸支流罗梭江生境比其他 一级支流更加复杂多样, 蕴育了更加丰富的鱼类物种多样性; 南腊河、南览河 ${ }^{[13]}$ 和南阿河均靠近边境, 人为干 
扰相对较少,开发强度有限,鱼类多样性仍保持较高水平;而流沙河、南果河、预养河、南肯河开发强度较大或 者流域面积较小,鱼类物种多样性较低。

虽然澜沧江西双版纳段土著鱼类较多,鱼类物种多样性也维持较高水平,但仍有一些流域或河段面临着 严重威胁,主要有以下几个原因:

(1)外来种的人侵。随着调查的深人, 西双版纳外来鱼类不断被发现, 从历史记录看, 西双版纳外来鱼类种 数占比逐渐升高, 而土著鱼类种数占比逐渐下降,与郑兰平等 ${ }^{[17]}$ 的研究结果基本一致。本次调查外来鱼类 27 种, 占比达 $22.69 \%$, 从优势度指数看, 外来鱼类尼罗罗非鱼为一般种,下口鲇 Hypostomus plecostomus 为少见 种, 但这些外来鱼类的生存能力强, 繁殖快, 数量急剧增加, 严重压缩了土著鱼类的生存空间, 对土著鱼类造成 较大威胁。

(2)河流生境破碎化。水电开发、水利工程等大型工程项目使河流的连通性受阻 ${ }^{[18,60-62]}$, 西双版纳澜沧江 干流目前建设有景洪水电站, 南腊河等一级支流也建设有中小型水电站, 这些水利水电工程的建设均导致了 河流生境破碎化, 对鱼类“三场” 和栖息地环境产生影响, 导致洄游鱼类的洄游通道受阻、土著鱼类的基因交 流减少,鱼类遗传多样性降低。

(3)水质污染。沿河两岸的城镇和农村生活污水、畜禽粪便等,农业面源污染物, 工业企业产生的废水等进 人河流,对鱼类的栖息环境产生威胁。

(4)捕捞强度过大。西双版纳澜沧江干支流捕捞强度过大, 非法捕鱼和电鱼活动屡禁不止, 特别是在鱼类 繁殖期对聚集产卵亲鱼的无序捕捞,使鱼类资源面临严重威胁。

\section{4 保护建议}

针对澜沧江西双版纳段鱼类组成特点、物种多样性变化和受威胁因素, 提出如下建议:

(1)严格控制外来鱼类入侵, 规避生态安全风险。要加大对外来鱼类的管控和治理力度, 严防养殖鱼类逃 逸到自然水体形成新的外来鱼类,进一步规避外来鱼类的人侵导致的生态安全风险。

(2)加大鱼类保护区的管理投入和生态监测。目前,西双版纳州设立有罗梭江鱼类自然保护区和澜沧江一 湄公河流域拿、双孔鱼保护区及普文河特有鱼类国家级水产种质资源保护区和南腊河特有鱼类国家级水产种 质资源保护区, 对西双版纳鱼类资源保护起到一定的积极作用,但这些保护区设立时间相对较短, 管理投人不 足, 缺乏系统的生态监测。因此,加强保护区的管理投人和生态监测尤为重要。

(3)减小河流的开发强度。要推进河流空间生态修复,有条件地拆除部分老旧引水式小型水电站,恢复鱼 类栖息地的连通性; 减少河道两侧挖沙采矿等活动, 在条件适宜的支流加强栖息地保护,进行生境修复, 建设 人工模拟产卵场等。

(4)减少水质污染。要有规划的使用化肥、农药,沿河农村生活污水、畜禽废水和工业废水等进行处理后再 排放,减少水质污染的风险。

(5)限制捕捞强度。要严格禁止 “电毒炸” 现象, 限制对产卵期亲鱼的捕捞, 加大监管和联合执法力度, 做 好鱼类多样性保护。

(6)推广河长制制度。要进一步加强鱼类保护意识的宣传和引导, 推广河长制, 突出社区保护的作用,把保 护的主体从政府部门向政府部门与当地社区协同联动方向转变。

(7)加大科研投人。支持土著、珍稀鱼类的驯养繁殖, 持续推进土著、珍稀鱼类的增殖放流力度和人工养殖 规模,减轻野生鱼类的捕捞压力。

致谢: 中国科学院昆明动物研究所王治邦、梁铀, 西双版纳州渔政监督管理站祁文龙、杨思庆, 西双版纳州林业 和草原局李志勇、周俊良,景洪市渔政监督管理站寇文辉,㔚海县渔政监督管理站萧志刚、王克强,㔚腊县渔政 监督管理站高志刚等在野外调查中给予帮助; 昆明动物研究所林峰、闵锐在标本整理鉴定中给予帮助, 李彦知 
在采样点分布图的制作中给予帮助,特此致谢。

\section{参考文献 (References) :}

[1] 周长进, 关志华. 澜沧江 (涺公河) 正源及其源头的再确定. 地理研究, 2001, 20(2)：184-190.

[2] 何大明, 汤奇成. 中国国际河流. 北京: 科学出版社, 2000.

[ 3 ] 杨岗, 李恒. 云南湿地. 北京: 中国林业出版社, 2010.

［４］李雪晴, 孙赫英, 何德奎, 陈毅峰. 澜沧江一湄公河中上游淡水鱼类多样性. 生物多样性, 2019, 27(10)：1090-1100.

[ 5 ] Rainboth W J. Fishes of the Cambodian Mekong. FAO Species Identification Field Guide for Fishery Purposes, Rome: FAO, 1996.

[ 6 ] Dudgeon D. Asian river fishes in the anthropocene: threats and conservation challenges in an era of rapid environmental change. Journal of Fish Biology, 2011, 79(6): 1487-1524.

[ 7 ] 陈永森, 吴坚, 朱万玉. 西双版纳自然保护区地质地貌考察报告//西双版纳自然保护区综合考察团. 西双版纳自然保护区综合考察报告 集. 昆明: 云南科技出版社, 1987.

[ 8 ] 龚德能, 王建皓. 西双版纳自然保护区气候考察报告//西双版纳自然保护区综合考察团. 西双版纳自然保护区综合考察报告集. 昆明: 云南科技出版社, 1987 .

[ 9 ] 杨德华. 西双版纳动物志. 昆明: 云南大学出版社, 1993.

[10］褚新洛，陈银瑞. 西双版纳的鱼类//西双版纳自然保护区综合考察团. 西双版纳自然保护区综合考察报告集. 昆明：云南科技出版 社, 1987.

［11］全国渔业自然资源调查和区划领导小组. 云南省渔业区划. 昆明: 云南省农业区划委员会, 1986.

[12] 康斌, 何大明. 澜沧江鱼类生物多样性研究进展. 资源科学, 2007, 29(5) : 195-200.

[13] 郑兰平, 陈小勇, 杨君兴. 云南省西双版纳州南拉河鱼类组成及其现状. 动物学研究, 2009, 30(3) : 334-340.

[14] 姚景龙. 澜沧江流域鱼类多样性与土著鱼类中华刀鲇的生物学 [D]. 中国科学院水生生物研究所, 2010.

[15］康斌, 胡文娴, 祈文龙, 杨春明, 李江红. 补远江鱼类多样性研究. 渔业科学进展, 2010, 31(3): 6-14.

[16] 刘明典, 陈大庆, 段辛斌, 王珂, 刘绍平. 澜沧江云南段鱼类区系组成与分布. 中国水产科学, 2011, 18(1)：156-170.

[17] 郑兰平, 陈小勇, 杨君兴. 澜沧江中下游鱼类现状及保护. 动物学研究, 2013, 34(6)：680-686.

[18] Zhang C, Ding L Y, Ding C Z, Chen L Q, Sun J, Jiang X M. Responses of species and phylogenetic diversity of fish communities in the Lancang River to hydropower development and exotic invasions. Ecological Indicators, 2018, 90: 261-279.

[19] 洪迎新, 施文卿, 陈宇琛, 刘东升, 马宏海, 朱吴或, 陈求稳. 水电梯级开发进程中澜沧江干流鱼类群落演变特征. 生态学报, 2021,41 (1) : 235-253.

[20] 张春霖. 云南西双版纳鱼类名录及一新种. 动物学报, 1962, 14(1): 95-98.

[21] 李树深. 中国鱼类新纪录. 动物学报, 1973, 19(3) : 305.

[22］何舜平, 陈毅峰. 云南鳃属鱼类一新种(鲤形目: 鲤科). 动物分类学报, 1994, 19(3): 375-377.

[23] 陈自明, 黄德昌, 徐世英, 祁文龙. 中国鲤科鱼类新纪录一一匹哇四须鲃. 动物学研究, 2003, 24(2): 148-150.

[24] Yang J, Chen X Y, Yang J X. A new species of the genus Mekongina Fowler, 1937 (Cypriniformes: Cyprinidae) from South China. Journal of Fish Biology, 2008, 73(8) : 2005-2011.

[25] Chen Z M, Zhang X Y, Qi W L, Deng X M, Xiao H. A new record of Anguillid fish in Lancangjiang River, China: Anguilla bicolor. Zoological Research, 2010, 31(4): 444-445.

[26] Kottelat M. The fishes of the Nam Theun and Xe Bangfai drainages, Laos. Hydroécologie Appliquée, 2016, 19: 271-320.

[27] Chen Z Y, Qin T, Chen X Y. A new genus record of Yasuhikotakia Nalbant, 2002 (Teleostei Botiidae) and a new species record of Brachydanio Weber et de Beaufort, 1916 (Teleostei Cyprinidae) to China. Biodiversity Journal, 2017, 8(2) : 719-724.

[28] Li X, Zhou W, Che X J. Loaches of Vanmanenia (Cypriniformes: Gastromyzontidae) from Yunnan, China with description of a new species. Zootaxa, 2019, 4603(1) : 125-144.

[29] 雷春云, 薛绍伟, 薛晨江. 中国安彦䲝属鱼类一新记录. 云南农业大学学报: 自然科学, 2019, 34(3): 553-554

[30］朱松泉. 中国条䲝志. 南京: 江苏科学技术出版社, 1989.

[31] 褚新洛, 陈银瑞. 云南鱼类志 (上册). 北京: 科学出版社, 1989.

[32] 褚新洛, 陈银瑞. 云南鱼类志 (下册). 北京: 科学出版社, 1990.

[33］朱松泉. 中国淡水鱼类检索. 南京: 江苏科学技术出版社, 1995.

[34] 褚新洛, 郑葆珊, 戴定远. 中国动物志 硬骨鱼纲 鲇形目. 北京: 科学出版社, 1999.

[35] 陈宜瑜. 中国动物志 中卷 硬骨鱼纲 鲤形目. 北京: 科学出版社, 1998. 
[36] 乐佩琦. 中国动物志 下卷 硬骨鱼纲 鲤形目. 北京: 科学出版社, 2000.

[37] Kottelat M. Fishes of Laos. Colombo: Wildlife Heritage Trust Publications, 2001.

[38] 陈小勇. 云南鱼类名录. 动物学研究, 2013, 34(4) : 281-343.

[39] 刘绍平, 刘明典, 张耀光, 曹特. 澜沧江水生生物物种资源调查与保护. 北京: 科学出版社, 2016.

［40］ 孙航，高正文. 云南省生物物种名录(2016版). 昆明: 云南科技出版社, 2017.

[41］薛晨江, 薛绍伟, 雷春云. 澜沧江下游土著鱼类图鉴. 昆明: 云南科技出版社, 2019.

[42］张觉民, 何志辉. 内陆水域渔业自然资源调查手册. 北京: 农业出版社, 1991.

[43］伍汉霖, 邵广昭, 赖春福, 庄棣华, 林沛立. 拉汉世界鱼类系统名典. 基隆, 中国: 水产出版社, 2012.

［44］国家林业和草原局，农业农村部. 国家林业和草原局 农业农村部公告(2021 年第 3 号) ( 国家重点保护野生动物名录)。(2021-02-05)。 http://www.forestry.gov.cn/main/3457/20210205/122612568723707.html.

[45] 环境保护部, 中国科学院. 关于发布《中国生物多样性红色名录——脊椎动物卷》的公告. (2015-05-20). http://www.9ask. cn/fagui/ 201505/46175_1.html.

[46] Pinkas L, Oliphant M S, Iverson I L K. Food habits of albacore, Bluefin tuna, and bonito in California waters. California Department of Fish and Game Fish Bulletin, 1971, 152: 1- 105.

[47] 蒋志刚, 纪力强. 鸟兽物种多样性测度的 G-F 指数方法. 生物多样性, 1999, 7(3) : 220-225.

[48］陈国柱, 仇玉萍, 李丽萍. 塔里木盆地鱼类人侵及区系演变趋势. 生态学报, 2017, 37(2)：700-714.

[49] Krebs C. Ecology : the Experimental Analysis of Distribution and Abundance. 2nd ed. New York: Harper \& Row Publishers, 1978.

[50] Pielou E C. Ecological Diversity. New York: John Wiley \& Sons Inc, 1975.

[51] Margalef R. Information theory in ecology. General Systems, 1958, 3: 36-71.

[52］刘振华, 何纪昌, 江望高. 云南澜沧江中游地区鱼类调查研究. 云南大学学报, 1987, 9(2): 146-150.

[53] 郭祖锋, 李林, 贺伟平, 李华良. 㴹沧江上游鱼类资源研究. 现代农业科技, 2014, (14) : 228-228, 237- 237.

[54] 朱图寿, 后永昆, 何德权, 纪永贵. 普洱土著鱼类颜色图谱. 昆明: 云南科技出版社, 2016.

[55] 杨君兴, 陈小勇, 陈银瑞. 中国澜沧江鲻科鱼类种群现状及洄游原因分析. 动物学研究, 2007, 28(1): 63-67.

[56] 刘飞, 林鹏程, 黎明政, 高欣, 王春伶, 刘焕章. 长江流域鱼类资源现状与保护对策. 水生生物学报, 2019, 43(S1): 144-156.

[57] 帅方敏, 李新辉, 何安尤, 刘乾甫, 张迎秋, 武智, 朱书礼. 珠江水系广西江段鱼类多样性空间分布特征. 水生生物学报, 2020, 44(4)： 819-828.

[58] 林诗芸. 补远江干流鱼类生境特征与鱼类多样性的关联研究 $[D]$. 昆明: 云南大学, 2016.

[59] 王莹. 㴹沧江中下游鱼类栖息地的水文、水力学特征研究 [D]. 北京: 中国水利水电科学研究院, 2015

[60］黄亮. 水工程建设对长江流域鱼类生物多样性的影响及其对策. 湖泊科学, 2006, 18(5) : 553-556.

[61] 茹辉军, 刘学勤, 黄向荣, 宁应之, 王洪铸. 大型通江湖泊洞庭湖的鱼类物种多样性及其时空变化. 湖泊科学, 2008, 20(1) : 93-99.

[62］陈美玲. 澜沧江梯级库区环境梯度对鱼类分布的影响及其机制 [D]. 昆明: 云南大学, 2021. 


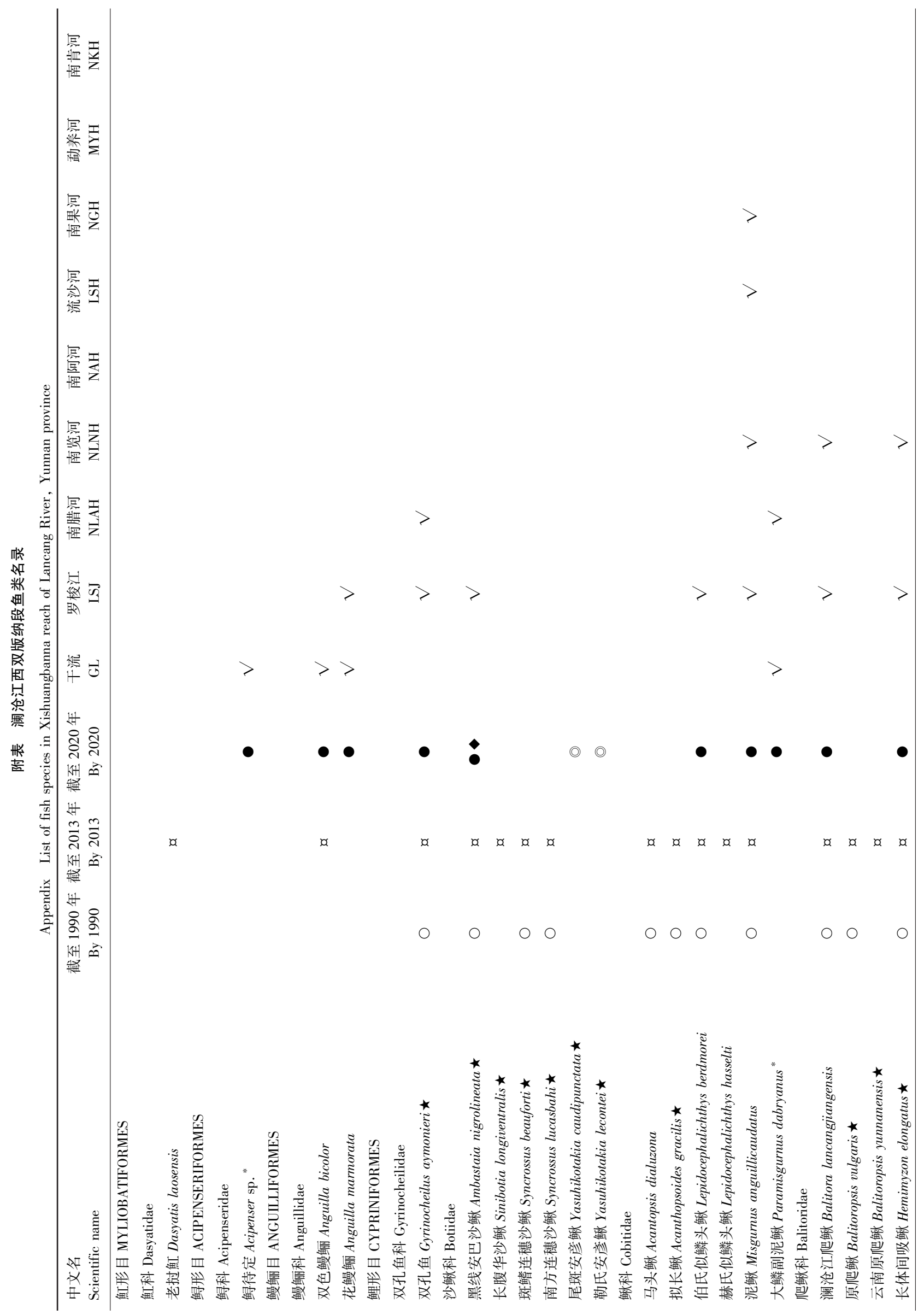




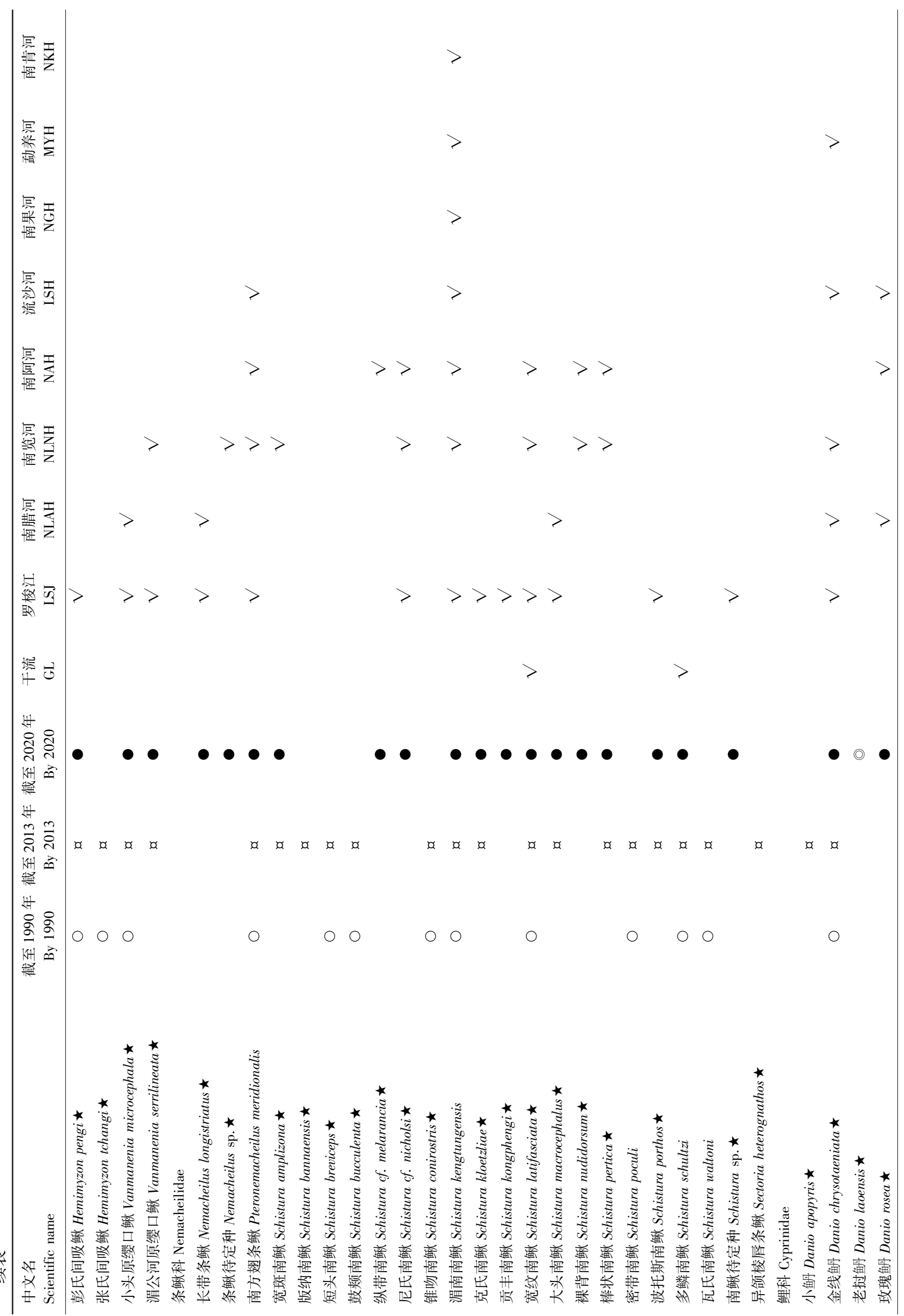




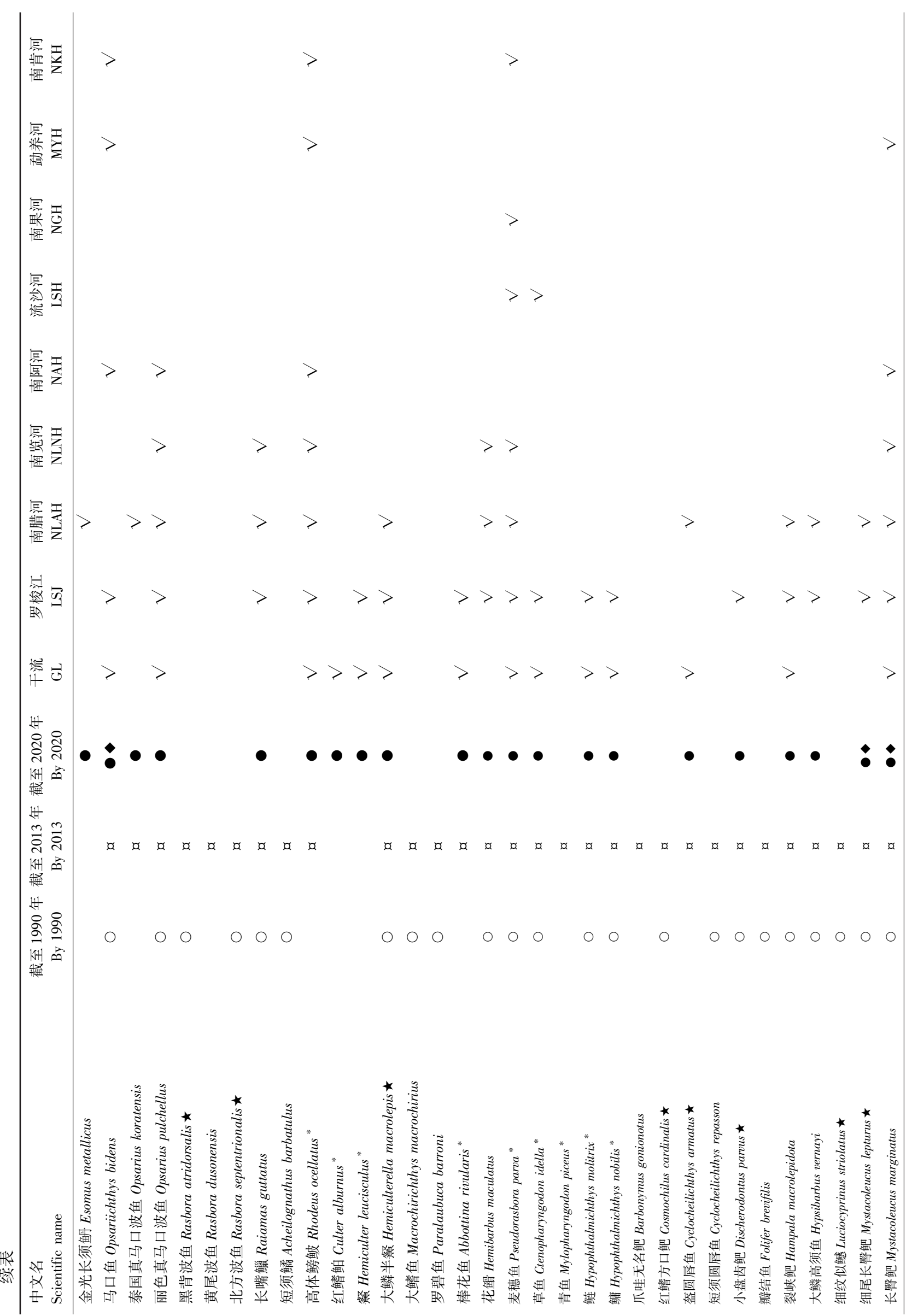




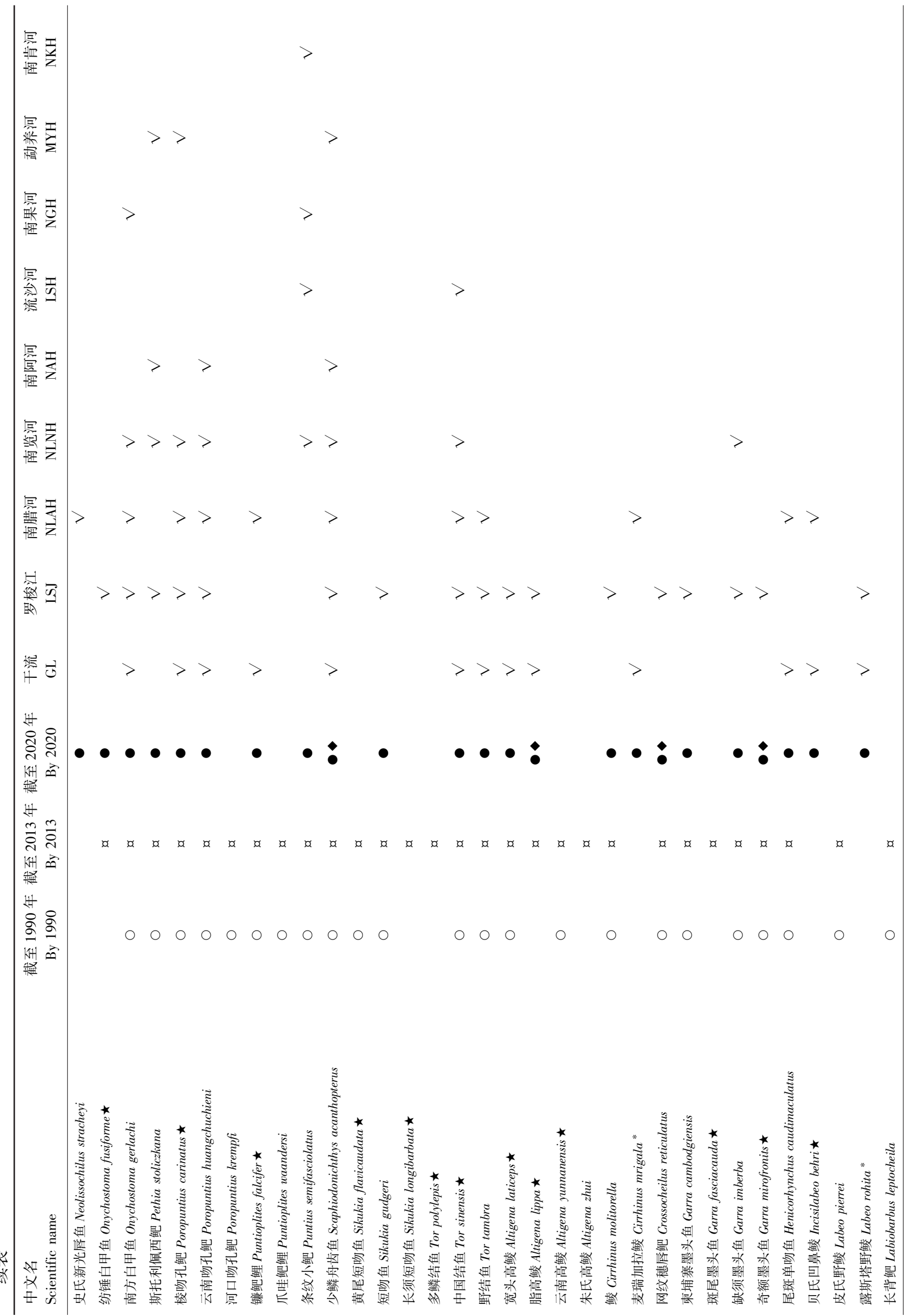




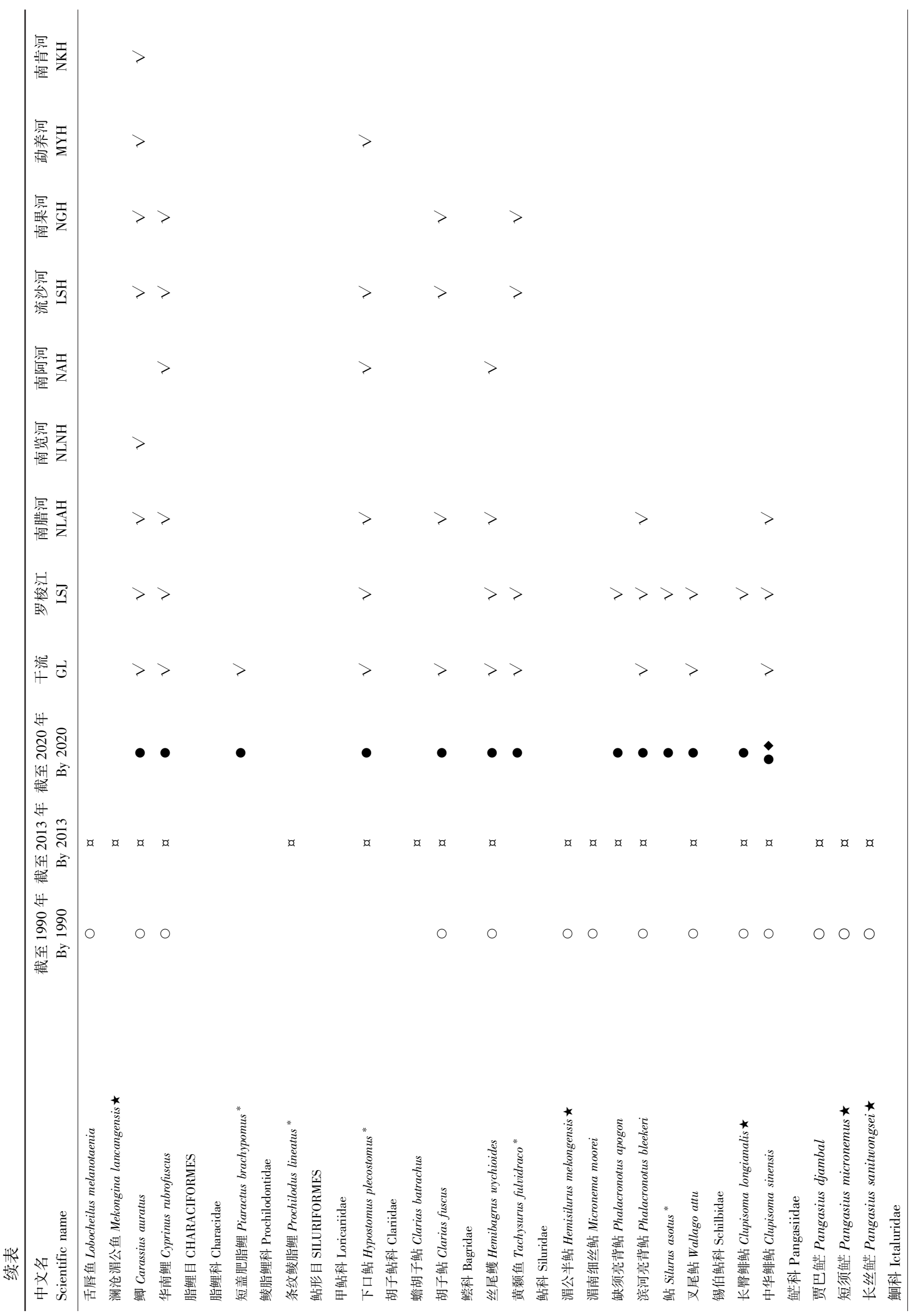




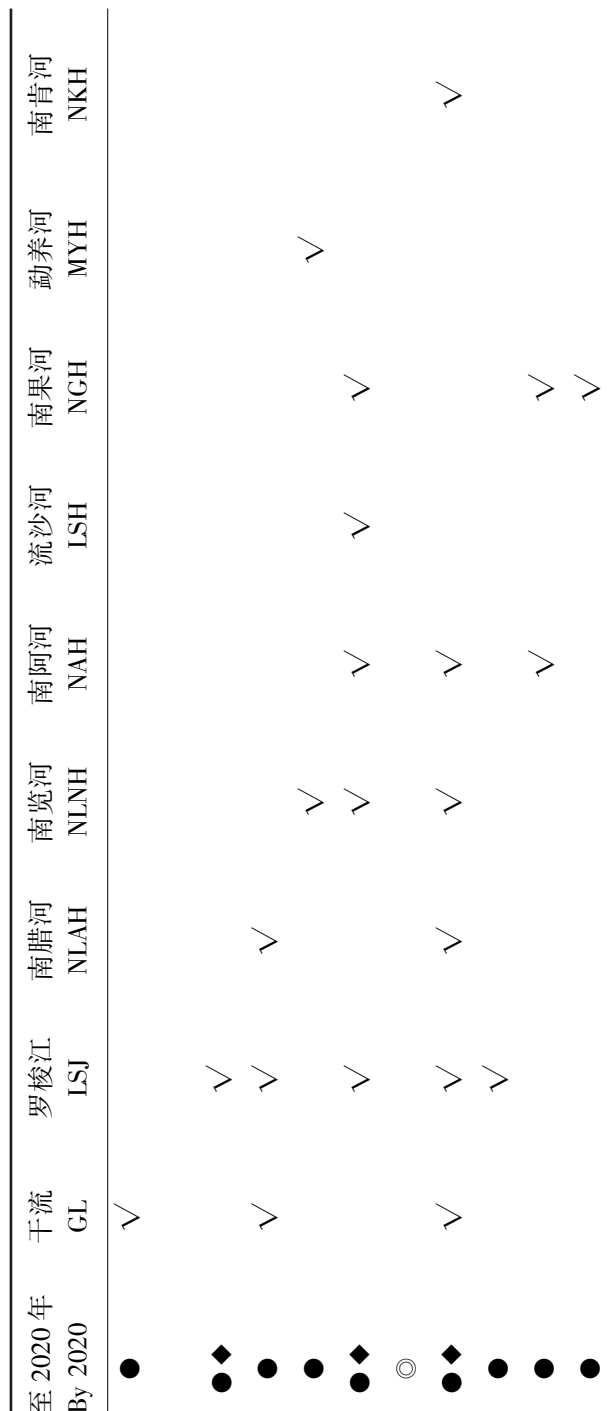




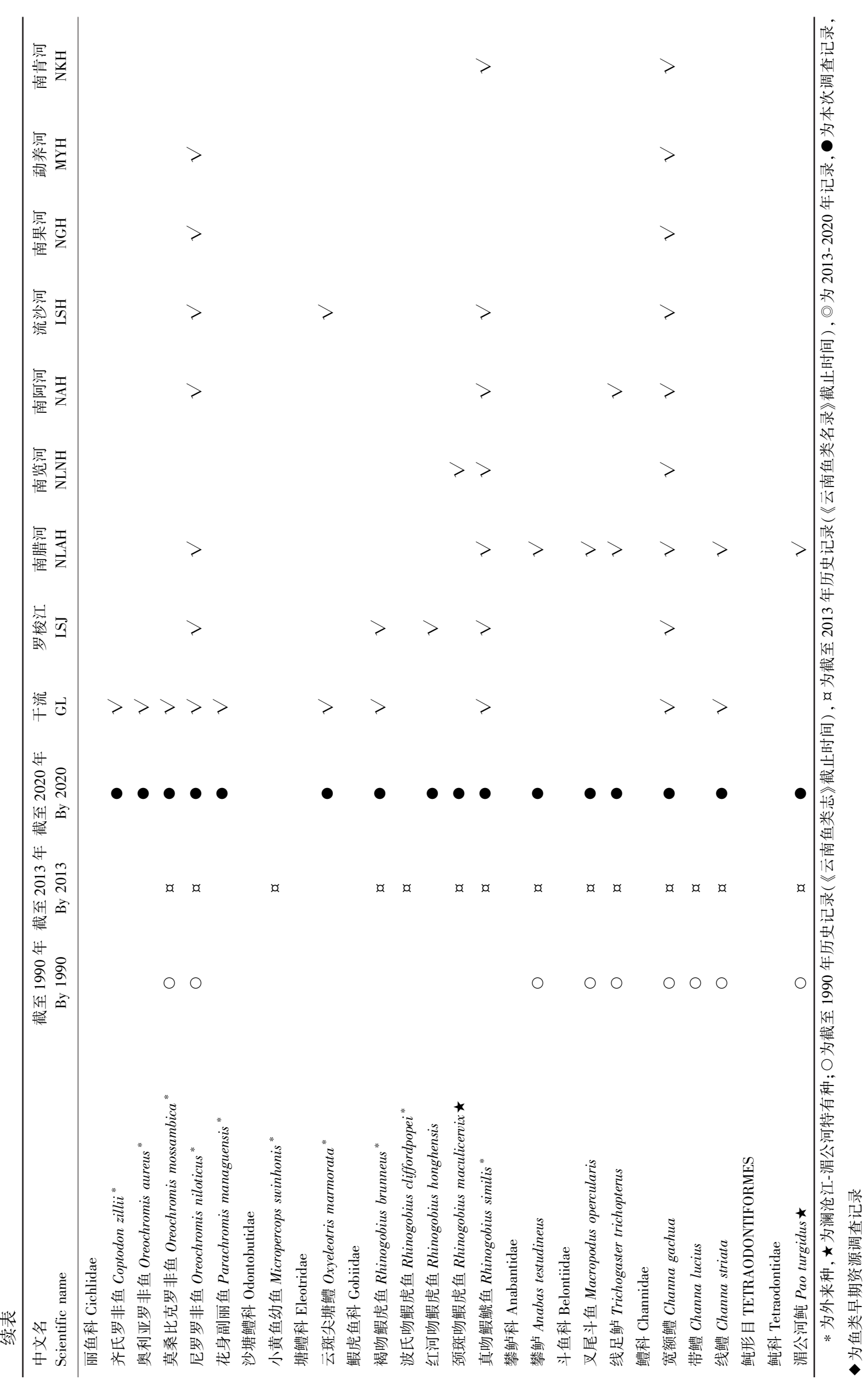

http ://www.ecologica.cn 